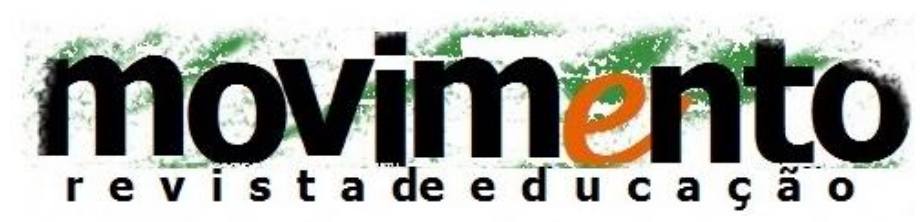

faculdade de educação - programa de pós-graduação em educação

universidade federal fluminense

issn 2359-3296

ano 3 número 5 - 2016

\title{
TEORIAS CRÍTICAS E PÓS-CRÍTICAS: pelo encontro em detrimento do radicalismo
}

\author{
Márden De Pádua Ribeiro1
}

\section{RESUMO}

O presente artigo tem por objetivo problematizar as ditas teorias pós-críticas de currículo. Trata-se de uma reflexão teórica que busca defender que atualmente, no campo curricular, vertentes pós-estruturais radicais tem induzido reflexões curriculares abstratas. O trabalho postula pela necessidade de um diálogo entre as vertentes críticas e pós-críticas de currículo, colocando-se em oposição às assertivas que advogam pelo fim da teoria crítica curricular, negando uma visão dicotômica, que resulta em uma ideia de ruptura e superação da vertente pós-crítica em relação à crítica. Para isso, amparase em teóricos críticos do currículo que atuam em constante diálogo com demais vertentes pós-modernas e pós-estruturais, atuando assim em uma zona fronteiriça conceitual.

Palavras-chave: Currículo. Teoria Crítica; Teoria Pós-Crítica.

\section{ABSTRACT}

This article aims to discuss the so-called curriculum of post-critical theories. This is a theoretical reflection that seeks to defend currently in the curriculum field, post-structural aspects radicals have induced abstract curricular reflections. The work posits the need for dialogue among the critical aspects and curriculum after critics by putting in opposition to assertions advocating the end of the course critical theory, denying a dichotomous view, resulting in a sense of rupture and overcoming strand post-critical in relation to critical. For this, we seek refuge in critical theorists of the curriculum that work in constant dialogue with other postmodern and post-structural aspects, thus acting in a conceptual border area.

Keywords: Curriculum. Critical Theory. Post-Critical Theory.

1 Doutorando em Educação - PUCMG. E-mail: mardendepadua@yahoo.com.br. 


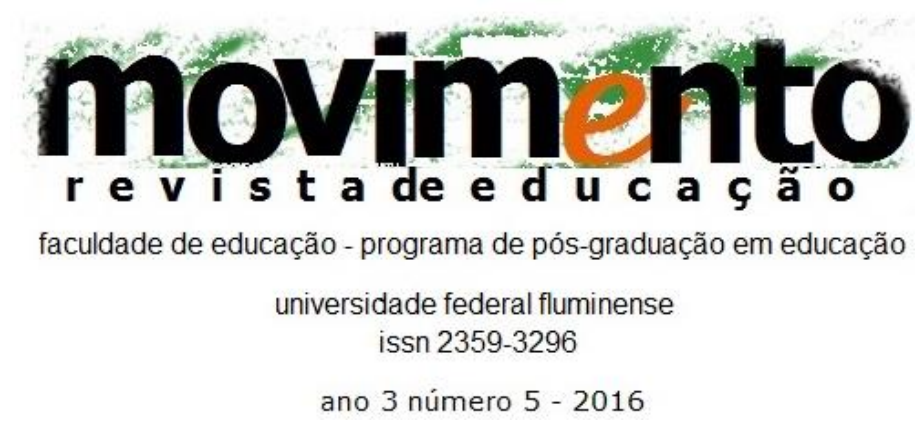

\section{Introdução}

A complexidade do campo curricular nos últimos anos tem sido de tal ordem que cada vez mais é difícil definir, por exemplo, as fronteiras entre críticos e póscríticos. As influências, no campo do currículo, dos estudos do cotidiano (FERRAÇO e CARVALHO, 2012; OLIVEIRA, 2013; ALVES, 2003); da filosofia da diferença (CORAZZA, 2001; 2008); das políticas de currículo na perspectiva de Stephen Ball (DIAS e LOPES, 2009; LOPES e MACEDO, 2011) se embaralham com as concepções de currículo rizomático (GALLO, 2010); de currículo como vetor-força (PARAísO, 2015); currículo como espaço-tempo de enunciação cultural (MACEDO, 2006); currículo como teia de significados (PEREIRA, 2012); do currículo atrelado à necessidade de transmissão do conhecimento poderoso (YOUNG, 2007,2011,2013). Mistura-se às discussões específicas de gênero, etnia, tecnologia, que demandam do campo curricular ressignificações teóricas.

O presente artigo, através de uma reflexão teórica, visa defender os pontos de encontro entre as vertentes crítica e pós-crítica buscando atuar em suas regiões fronteiriças, estabelecendo uma crítica a uma concepção aqui nomeada como pós-crítica radical.

A ideia de uma vertente pós-crítica permite inferir uma superação sobre a vertente crítica a partir do termo pós. Desse modo, é como se tal concepção não acolhesse nenhuma premissa das teorias curriculares críticas, e de outro modo, é como se as teorias críticas estivessem superadas, impossibilitando o entendimento de que estas passaram a absorver diversas contribuições póscríticas, através do acolhimento de algumas abordagens pós-modernas e pós- 


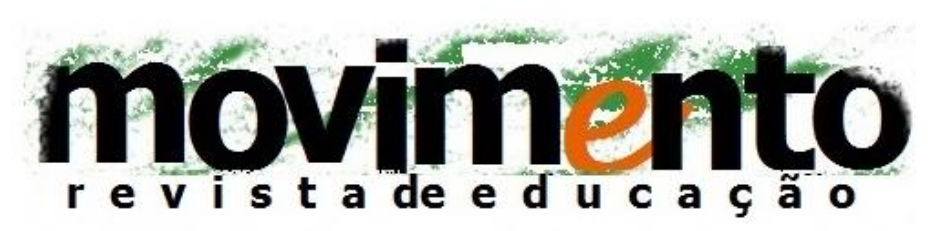

faculdade de educação - programa de pós-graduação em educação

universidade federal fluminense issn 2359-3296

ano 3 número 5 - 2016

estruturais. Impossibilita ainda outra possível interpretação de que as teorias chamadas pós-críticas são na verdade teorias críticas sob outras ênfases.

Autores tidos como críticos, na ótica de Silva (2009), têm, nos últimos tempos, acolhido diversas contribuições pós-modernas no tocante à problematização da universalidade do conhecimento, desconfiança em relação a algumas metanarrativas, questionamento da ideia de verdade e de racionalidade plena. Em seus trabalhos, Michael Apple, Henri Giroux, Peter McLaren são explícitos em acolher contribuições tidas como pós-críticas sem, no entanto, abandonarem algumas premissas da teoria crítica: a ideia de hegemonia, de emancipação e a busca pela transformação social. Esses híbridos teóricos (LOPES, 2013) dão a dimensão da importância de se problematizar, nos dias atuais, a já clássica classificação: tradicionais, críticos e pós-críticos, sobretudo as duas últimas.

Onde reside a fronteira entre críticos e pós-críticos? Lopes (2013) explicita a dificuldade do termo pós-crítico de abarcar toda uma multiplicidade de vertentes pós-modernas que são heterogêneas entre si. Já a teoria crítica, há muito tempo abandonou as premissas cartesianas, plenamente racionais que Silva (2000) denuncia em seu texto: Os fantasmas da Pedagogia Crítica, ao proclamar o fim da teoria crítica. Atuar em uma zona fronteiriça entre críticos e pós-críticos é desafio fundamental que o presente artigo se propõe, o que demanda por uma desestabilização do enquadramento que os separam e que sutilmente coloca a teoria pós-crítica como algo que supera a teoria crítica, a partir do advento da pós-modernidade, como defende Silva $(2000,2009,2010)$ em seus recentes trabalhos.

Parte-se aqui então da seguinte premissa teórica: as teorias pós-críticas estão inegavelmente marcadas pela influência do pós-modernismo e do pós- 


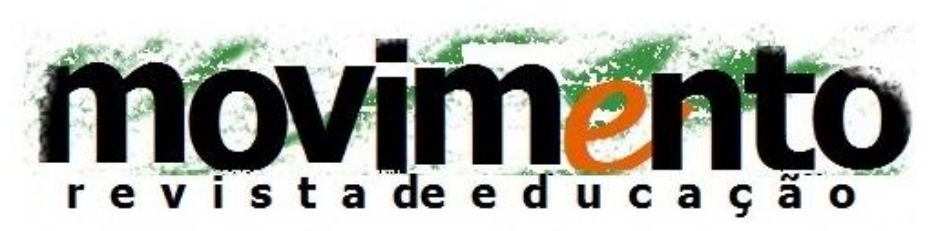

faculdade de educação - programa de pós-graduação em educação

universidade federal fluminense issn 2359-3296

ano 3 número 5 - 2016

estruturalismo (SILVA, 2009; MACEDO, 2006; PARAÍSO, 2004; LOPES, 2013). Desse modo, cria-se uma dicotomia, principalmente através dos recentes trabalhos de Tomaz Tadeu Silva, de que à teoria crítica relegou-se a influência da chamada Modernidade: racionalista, cartesiana, universalista. Assim, a teoria pós-crítica seria uma superação da teoria crítica do mesmo modo que a pósmodernidade seria uma superação dos paradigmas da Modernidade. O presente artigo visa desestabilizar tais premissas, ressaltando que a vertente curricular crítica tem se ressignificado ao longo do tempo, acolhendo premissas pósmodernas, hibridizando-as com premissas tipicamente modernas: totalidade, emancipação, autonomia, transformação social.

\section{Discutindo pós-modernismo e pós-estruturalismo}

A influência do pós-modernismo no campo da teoria curricular não é fenômeno tão recente assim. Já há quase vinte anos, Moreira (2003, p.9) constata tal presença: tem-se acentuado, nos últimos anos, a influência do pensamento pósmoderno no discurso curricular contemporâneo, tanto no Brasil como em outros países. Elizabeth Macedo (2013, p.438) faz a mesma constatação, afirmando que a partir da década de noventa, a hegemonia quase absoluta do pensamento marxista entra em declínio nos estudos curriculares, com a forte incorporação, pelo campo, de perspectivas pós-estruturais.

As categorias pós-críticas seriam aquelas correntes identificadas com o pósmodernismo e pós-estruturalismo, ainda que heterogêneas, mas que buscam premissas diferentes das vertentes críticas e se consolidam no sentido de superação da concepção curricular crítica. Segundo o quadro teórico elaborado 


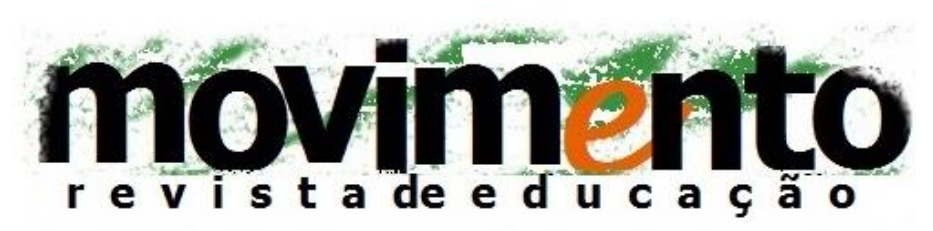

faculdade de educação - programa de pós-graduação em educação

universidade federal fluminense issn 2359-3296

ano 3 número 5 - 2016

por Silva (2009), os pós-críticos enfatizam a cultura, o gênero, a etnia, a diferença e a linguagem. Já os críticos ressaltam o poder, a economia, a classe social e o conflito. $\mathrm{O}$ autor desconsidera possibilidades de hibridismos teóricos entre as vertentes, como por exemplo, na questão da cultura: central para os críticos e também pós-críticos.

A influência do pós-modernismo no campo da teoria curricular não é fenômeno tão recente assim. Moreira (2003, p.9) já havia constatado tal fenômeno: tem-se acentuado, nos últimos anos, a influência do pensamento pós-moderno no discurso curricular contemporâneo, tanto no Brasil como em outros países. Elizabeth Macedo (2013, p.438) faz a mesma constatação, afirmando que a partir da década de noventa, a hegemonia quase absoluta do pensamento marxista entra em declínio nos estudos curriculares, com a forte incorporação, pelo campo, de perspectivas pós-estruturais.

As teorias pós-críticas, portanto, são resultado da ascensão do pós-modernismo como uma corrente teórica que influenciou diretamente o campo curricular. Peters (2000, p.16) sugere algumas premissas básicas da acepção pósmoderna que, independente da heterogeneidade de seu significado, se mantém consolidadas: [...] não existe qualquer denominador comum - a natureza ou a verdade ou Deus ou o futuro - que garanta que o mundo seja Uno ou a possibilidade de um pensamento natural ou objetivo. Essa desconfiança em relação a conceitos totalizantes, comuns na modernidade, constitui-se como condição básica para que a pós-modernidade apresente-se como ruptura.

Em outras palavras, a pós-modernidade nos dizeres de Lyotard (1984) seria a desconfiança, a recusa na crença das metanarrativas e no sujeito emancipado através de uma progressiva consolidação da razão. Segundo Peters (2000), 


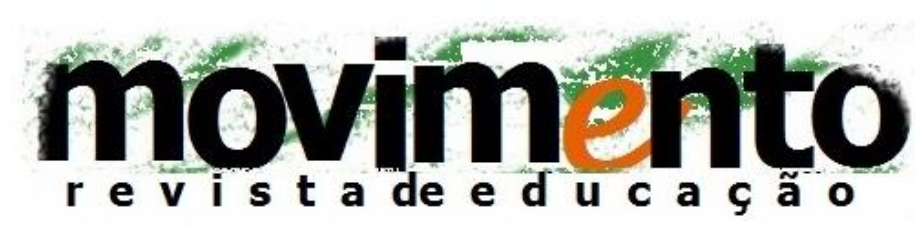

faculdade de educação - programa de pós-graduação em educação

universidade federal fluminense

issn 2359-3296

ano 3 número 5 - 2016

estas grandes narrativas, são nada mais, nada menos, do que histórias que determinadas culturas contam sobre suas próprias crenças e práticas, no intuito de respaldá-las. Ao consolidar tais desconfianças, o pós-modernismo se apresenta como uma concepção filosófica que representa uma alternativa ao paradigma moderno. Moreira (2003) sintetiza características comuns acerca do ideário pós-moderno:

a) o abandono das grandes narrativas; b) a descrença em uma consciência unitária, homogênea, centrada; c) a rejeição da ideia de utopia; d) a preocupação com a linguagem e com a subjetividade; e) a visão de que todo discurso está saturado de poder; f) a celebração da diferença (MOREIRA, 2003, p.10).

A síntese acima de Moreira (2003) vai ao encontro com o que Lyotard (1984) ressalta a respeito do pós-modernismo, ao também analisá-lo sob o prisma da ruptura com as grandes narrativas, da crítica à consciência unitária, autocentrada e universalista de sujeito - típico da Modernidade - e a descrença da ideia de utopia. Tais noções são corroboradas nas palavras de Eagleton:

[...] pós-moderno quer dizer, aproximadamente, o movimento de pensamento contemporâneo que rejeita totalidades, valores universais, grandes narrativas históricas, sólidos fundamentos para a existência humana e a possibilidade de conhecimento objetivo. O pós-modernismo é cético a respeito de verdade, unidade e progresso, apõe-se ao que vê como elitismo na cultura, tende ao relativismo cultural e celebra o pluralismo, a descontinuidade e a heterogeneidade (EAGLETON, 2005, p. 27).

No que tange aos objetos teóricos a que se destinam, pós-modernismo e o pósestruturalismo são diferentes: o primeiro enfatiza a articulação com o modernismo e o segundo com o estruturalismo. Reduzir o pós-estruturalismo a uma espécie de pós-modernidade específica é, no nosso entendimento, 


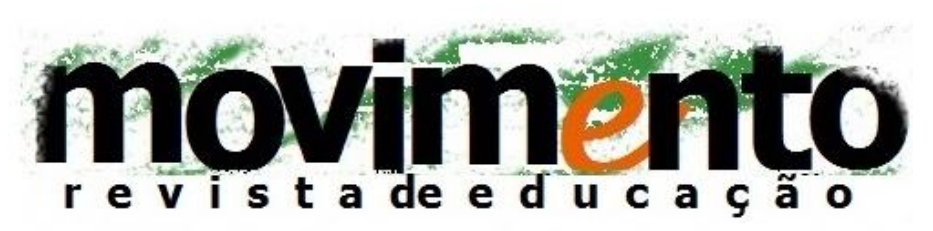

faculdade de educação - programa de pós-graduação em educação

universidade federal fluminense issn 2359-3296

ano 3 número 5 - 2016

empobrecer a complexidade e heterogeneidade que o constitui. No entanto, é inegável que existem premissas em comum no que diz respeito ao pósestruturalismo e em sentido mais amplo, ao pós-modernismo. Se as saídas oferecidas são múltiplas, as críticas realizadas se aproximam: ambos recusam as metanarrativas, desconfiam do paradigma de sujeito autônomo, centrado e crítico, enfatizam o local, o parcial, a linguagem, a diferença. Desconfiam do conhecimento universal e da noção de totalidade.

\section{As vertentes pós-críticas radicais: discursos curriculares abstratos}

Paraíso (2004, p.284), ao mapear os estudos pós-críticos no campo do currículo, constata que tal vertente recebe influências da chamada filosofia da diferença, do pós-estruturalismo, do pós-modernismo, da teoria quer, dos estudos feministas e de gênero, dos estudos multiculturalistas, pós-colonialistas, étnicos, ecológicos etc. Assim, a autora ressalta ainda que as teorias pós-críticas realizam, no campo educacional brasileiro, substituições, rupturas e mudanças de ênfases em relação às pesquisas críticas. Suas produções e invenções têm pensado práticas educacionais, currículos e pedagogias que apontam para a abertura, a transgressão, a subversão, a multiplicação de sentidos e para a diferença (PARAíSO, 2004, p.284-285).

Percebe-se claramente a importância de Tomaz Tadeu Silva na divulgação das vertentes pós-críticas para o campo curricular. Traduzindo e organizando obras desse caráter, o autor é o responsável crucial pela consolidação e hegemonia do paradigma pós-moderno e pós-estrutural nos estudos curriculares da atualidade. É o que Paraíso (2004) denomina como contágio ao concluir que tais 


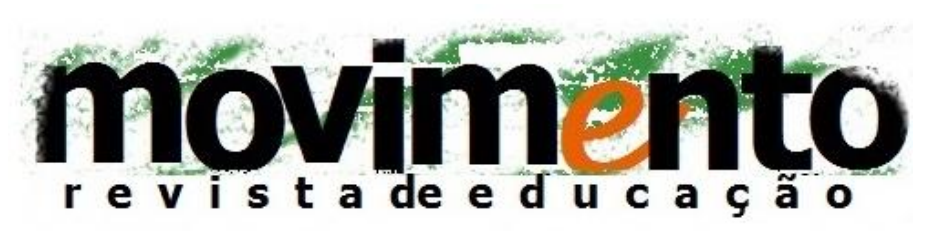

faculdade de educação - programa de pós-graduação em educação

universidade federal fluminense issn 2359-3296

ano 3 número 5 - 2016

concepções são hoje majoritárias na produção curricular. Tal constatação permanece sólida, na medida em que Thiesen (2015) em recente trabalho apresentado na ANPEd, chegou a mesma conclusão de Paraíso (2004).

As pesquisas pós-críticas em educação no Brasil, segundo Paraíso (2004), não acolhem a ideia de explicações universais, nem de totalidades, não aceita noções de completudes ou plenitudes. Em vez disso, optam claramente por explicações e narrativas parciais, pelo local e pelo particular (PARAísO, 2004, p. 288). Não se preocupam também com comprovações daquilo que já foi sistematizado na educação, nem com revelações ou descobertas (idem). Preferem, nas palavras de Corazza (2001, p.34), a invenção, a criação, o artefato, a produção.

Não acreditam na autonomia do sujeito ou da subjetividade e consideram o sujeito, basicamente um efeito discursivo, textual, (sob forte influência foucaultiana) em meio a processos de subjetivação. Estruturar as teorias curriculares como tradicionais, críticas e pós-críticas (SILVA, 20009) cumpre papel didático e serve como um pontapé inicial para que se introduzam as primeiras noções teóricas do campo curricular, percebendo as distinções entre elas.

No entanto, há dentro das teorias pós-críticas uma heterogeneidade conceitual que congrega tanto tentativas de pontos de encontro entre críticos e pós-críticos (PACHECO, 2016), quanto abordagens extremamente influenciadas pelos discursos pós-estruturais que acabam por filosofizar o campo curricular (MOREIRA, 2010, p.87) e dotá-lo de tal abstração que se recusa a oferecer qualquer tipo de alternativa concreta à realidade do cotidiano escolar. Esses estudos, nomeados por nós como pós-críticos radicais partem de uma 


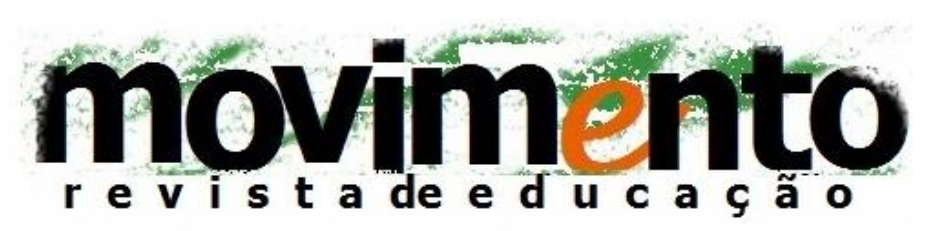

faculdade de educação - programa de pós-graduação em educação

universidade federal fluminense issn 2359-3296

ano 3 número 5 - 2016

apropriação das obras filosóficas de Gilles Deleuze, Félix Guatarri e Jacques Derrida, para o campo do currículo, através de engrenagens teórico-discursivas que, de tão abstratas, embora refinadas, pouco oferecem de concreto aos desafios diários educacionais, deixando lacunas importantes para outros setores, principalmente empresariais, elaborarem suas propostas concretas. Tais estudos radicalmente pós-críticos, podemos perceber principalmente em Silva (2000, 2010), Corazza (2001, 2008); Gallo (2010); e em algumas teses orientadas pelos dois primeiros teóricos mencionados: teses de Araújo (2007), Jacques (2011) e Girotto (2011).

Centraremos esforços primeiramente em Tomaz Tadeu Silva, enfatizando seus trabalhos que identificam os teóricos críticos como aqueles portadores de uma concepção de sujeito amparado sob o paradigma moderno-cartesiano, defensores de um universalismo portador da verdade-crítica absoluta, apta a transformar a sociedade, entendida de modo homogêneo (SILVA, 2000). O sujeito, nessa perspectiva é dotado de pretensa racionalidade plena e desse modo, visa interferir ativamente na sociedade, geralmente visando sua transformação. Silva (2000) tece críticas a essas formulações:

[...] senhoras e senhores, lamentamos informar que o sujeito da educação já não é mais o mesmo. Este parece ser o anúncio mais importante da teoria cultural e social recente. O sujeito racional, crítico, consciente, emancipado ou libertado da teoria educacional crítica entrou em crise profunda (SILVA, 2000, p.13).

Silva (2000), portanto, ressalta que as teorias críticas curriculares defendem uma concepção de sociedade no singular e apta a ser transformada pelo suposto sujeito crítico, cartesiano, plenamente racional e portador de uma verdade crítica absoluta. 


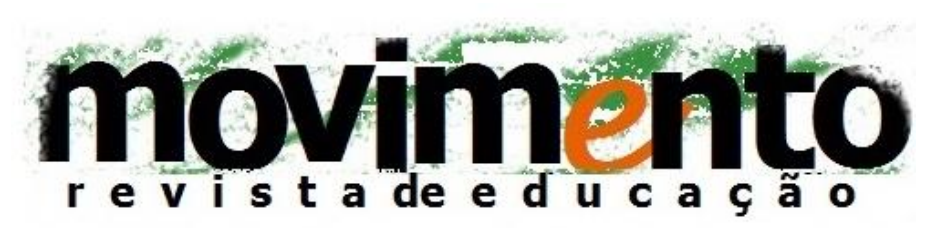

faculdade de educação - programa de pós-graduação em educação

universidade federal fluminense

issn 2359-3296

ano 3 número 5 - 2016

O sujeito crítico da pedagogia crítica é a réplica perfeita do sociólogo crítico da educação que, de sua posição soberana - livre dos constrangimentos que produzem a turvada compreensão da sociedade que têm os indivíduos comuns , vê a sociedade como se vê um mecanismo de relógio, tornando-se apto, assim, a consertá-la (SILVA, 2000, p.12-13).

Mais adiante, o autor relaciona esta concepção de sujeito a um viés cartesiano, oriundo do início da Idade Moderna, calcada na clássica afirmativa do filósofo René Descartes: penso, logo existo. Essa frase ficaria marcada em uma concepção racional, centrada e unificada de sujeito que, com o advento da pósmodernidade, sobretudo após influência da Psicanálise, sofreu forte abalo. Tal visão a respeito da racionalidade cartesiana presente em René Descartes é relativizada por Touraine (2008) que embora acolha o referido pensador como um dos expoentes da Modernidade, ressalta por outro lado seu dualismo filosófico que acaba por diminuir um pouco a visão estritamente racionalista geralmente atribuída a Descartes.

Silva (2000), após atrelar a teoria crítica a uma corrente defensora do paradigma cartesiano de sujeito, critica ainda duas premissas, segundo ele centrais na teoria crítica: a ideia de que existe uma sociedade no singular e a visão de que a teoria crítica irá formar a consciência crítica dos sujeitos para modificar essa sociedade. A persistente consigna que tem estado no centro de todas as vertentes dessa pedagogia pode ser sintetizada na fórmula 'formar a consciência crítica' (SILVA, 2000, p.16). Para ele, a teoria curricular crítica parte sempre do mesmo pressuposto: que existe algo como um núcleo essencial de subjetividade que pode ser pedagogicamente manipulado para fazer surgir o seu avatar crítico (idem, p.16). Esse avatar crítico, vê a si próprio e à sociedade de forma homogênea, adquirindo, no processo, a capacidade de contribuir para 


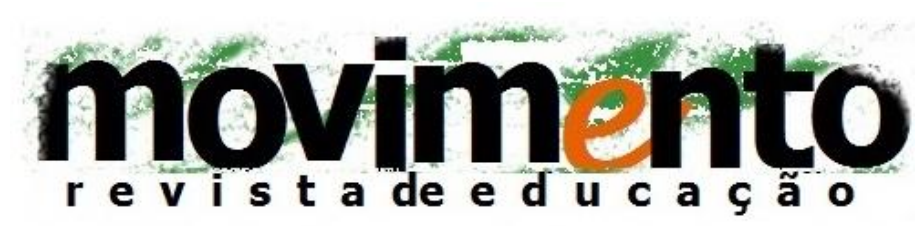

faculdade de educação - programa de pós-graduação em educação

universidade federal fluminense

issn 2359-3296

ano 3 número 5 - 2016

transformá-la. Ancorado na perspectiva pós-estrutural, o autor vai tecendo sua visão a respeito do sujeito:

é com a chamada teoria pós-estruturalista e com as perspectivas chamadas de pós-modernas, entretanto, que a teoria do sujeito vai se tornar claramente insustentável. Com Foucault, o sujeito não passa de um efeito das práticas linguísticas e discursivas que o constroem como tal. Se, para a Psicanálise, o sujeito não é quem ele pensa que é, para Foucault, o sujeito não é nada mais do que aquilo que dele se diz. O sujeito, mais do que originário e soberano, é derivado e dependente. $O$ sujeito que conhecemos como base e fundamento da ação é, na verdade, um produto da história (SILVA, 2000, p.15).

O autor, com alguma ironia, enquadra toda a teoria crítica reafirmando a concepção de fórmula que se encontra em crise e desacreditada. Denunciando e questionando a ideia de uma suposta consciência crítica, o autor afirma que tal visão é fruto de uma pretensão totalizante insustentável nos dias atuais.

Esta rica e querida fórmula já não nos parece tão tranqüila. Poucos acreditam, hoje, numa visão transparente da sociedade, a qual, para começar, supõe uma concepção da sociedade como única e unificada. Além disso, a soberana posição de uma consciência crítica baseia-se no pressuposto da existência de uma teoria total da sociedade que se torna insustentável num contexto no qual as metanarrativas de qualquer gênero são olhadas com profunda desconfiança (SILVA, 2000, p.13).

Para Silva (2009), o ponto de abalo da concepção curricular crítica consiste no advento do pós-modernismo. Assim, tal concepção crítica passa a conhecer seus limites através da vertente pós-moderna e pós-estrutural. Segundo Silva (2009, p.115) a pedagogia crítica jamais deixou de supor cenários em que reinavam uma certa certeza, e é justamente nessa certeza fundacional que atua 


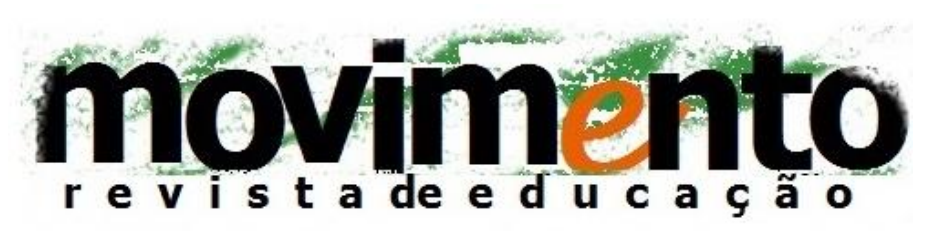

faculdade de educação - programa de pós-graduação em educação

universidade federal fluminense issn 2359-3296

ano 3 número 5 - 2016

o pós-modernismo: negando-a, rompendo-a, deslocando-a para o plano da incerteza. De acordo com Silva (2009, p.115), o pós-modernismo de certa forma, constitui uma radicalização dos questionamentos lançados às formas dominantes de conhecimento pela pedagogia crítica. Essa radicalização resulta, na eliminação de qualquer pretensão de emancipação. Em outras palavras, o pós-modernismo assinala o fim da pedagogia crítica e o começo da pedagogia pós-crítica. (SILVA, 2009, p.116).

É perceptível que Tomaz Tadeu Silva passou a enxergar a teoria crítica curricular de modo mais radical, dando a entender claramente que tal vertente se encontra superada pela vertente tida como pós-crítica. O autor passou a enquadrar a teoria crítica dentro de pressupostos homogeneizantes contribuindo assim para uma estagnação da vertente curricular crítica que não se coaduna com o desenvolvimento conceitual de seus autores ao longo dos anos. Desse modo, o autor radicaliza sua influência pós-estrutural elevando a recusa da possibilidade de intervenção do sujeito em sua realidade e relegando a teoria curricular crítica a uma vertente ultrapassada, estagnada no mais simplista cartesianismo ultraracional.

Outros estudos pós-críticos radicais optam por trazer definições transgressoras de currículo, ao invés de centrarem esforços nas críticas à teoria curricular crítica, embora também o façam em menor grau (GALLO, 2010; CORAZZA, 2001, 2008). Pretendemos mostrar, aqui, que nos momentos que tais concepções tentam oferecer alternativas aos sujeitos da educação, o fazem de modo tão vago, transgressor, poético que acaba por dificultar qualquer tentativa mínima de se pensar o currículo sob o viés da defesa de projetos societários específicos. 


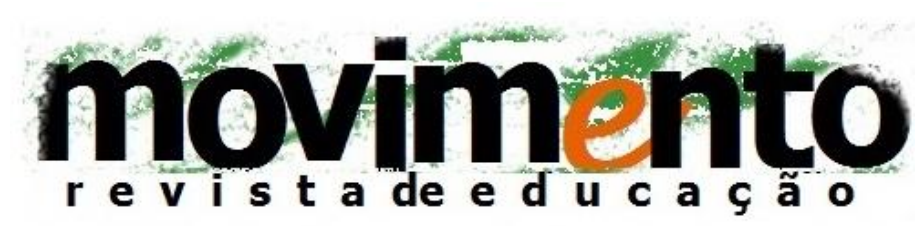

faculdade de educação - programa de pós-graduação em educação

universidade federal fluminense

issn 2359-3296

ano 3 número 5 - 2016

Gallo (2010) busca, no conceito de rizoma formulado por Deleuze, uma alternativa para se pensar o currículo para além da disciplinarização, em busca de uma transdisciplinaridade. Assim, defende a substituição da noção de conhecimento como árvore2 (através da metáfora de René Descartes) para um paradigma de currículo rizomático. Nessa acepção, diferentemente da ideia de árvore, não há galhos que partem de uma única raiz. Com o rizoma as coisas se passam de maneira distinta. Sua imagem remete para uma miríade de linhas que se engalfinham, como num novelo de lã emaranhado pela brincadeira do gato (GALLO, 2010, p.233). O autor acrescenta: um rizoma é promiscuidade, é mistura, mestiçagem, é mixagem de reinos, produção de singularidades sem implicar no apelo à identidade (idem).

Ao especificar mais seu pós-estruturalismo rizomático-deleuziano, o autor parte para a teorização do caos, em oposição a uma pedagogia da ordem, disciplinarizada e hierarquizada. Assim, uma pedagogia do caos, para Gallo (2010), aposta na multiplicidade, na abertura total para novas experiências, que visa desmontar qualquer tentativa proposta de unidade e coesão. O autor destaca que um currículo rizomático aventura sem bússolas pelos mares da multiplicidade de saberes (GALLO, 2010, p.237). Isto é, escapa de qualquer controle ou ordem e mergulha no caos por mais estranho, feio e assustador que se possa parecer (idem). Assim, sintetiza sua proposta de currículo rizomático-caótico:

2 René Descartes visto por muitos como uma espécie de pai da modernidade criou uma imagem interessante para o conjunto dos conhecimentos: a árvore dos saberes. Nessa imagem, as raízes da árvore representariam o mito, como conhecimento originário; o tronco representaria a filosofia, que dá consistência e sustentação para o todo; os galhos, por sua vez, representariam as diferentes disciplinas científicas, que por sua vez se subdividem em inúmeros ramos. Interessante notar que a imagem da árvore, por mais que dê vazão ao recorte, à divisão e às subdivisões, remete sempre de volta à totalidade, pois há uma única árvore, e para além do conhecimento das partes, podemos chegar ao conhecimento do todo, isto é, tomando distância podemos ver a árvore em sua inteireza. 


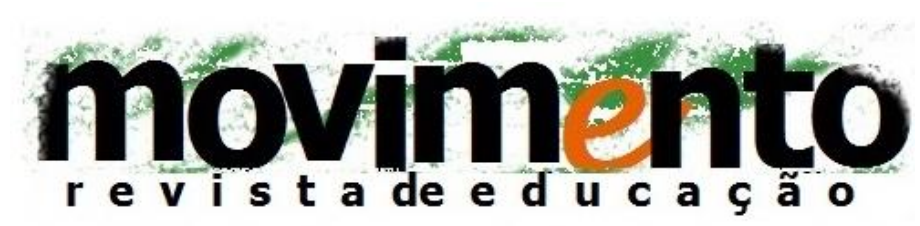

faculdade de educação - programa de pós-graduação em educação

universidade federal fluminense

issn 2359-3296

ano 3 número 5 - 2016

\begin{abstract}
Rizoma. Transversalidade. Caos. Currículo rizomático. Fluxos e percursos transversais. Pedagogia do caos. Que todas essas imagens não nos paralisem o pensamento, mas ao contrário, nos façam pensar, nos coloquem o desafio de pensar e produzir uma educação para além dessa que sofremos e fazemos sofrer no cotidiano de nossas salas de aula. Assim como os ratos fazem rizoma, assim como a vespa e a orquídea fazem rizoma, façamos rizomas com nossos alunos, estimulemos que eles façam rizoma entre si. Instituamos a promiscuidade e a mestiçagem na sala de aula. Pedagogia mestiça, pedagogia promíscua, pedagogia do caos (GALLO, 2010, p. 239).
\end{abstract}

Entendemos que tais assertivas, ainda que rebuscadas e refinadas, oferecem pouco ao cotidiano concreto de educadores e educandos que, a bem da verdade, travam batalhas diárias na dura realidade do dia a dia e necessitam através de um diálogo com eles e não para eles, de alternativas mais concretas às suas práticas.

Propagar fazer rizoma com alunos, do mesmo modo que ratos e orquídeas o fazem, pode ter um efeito discursivo interessante, mas possui pouco efeito prático e não chega perto de tocar nas questões de desigualdade social que estruturalmente impactam de modo profundo os sujeitos escolares. Tais assertivas também passam longe de problematizar as demandas urgentes e imediatas que dizem respeito principalmente à questão da escola.

Também flertando intensamente com a abstração, os trabalhos de Corazza (2001, 2005, 2008) recebem forte influência dos teóricos pós-estruturais já citados e também se apropria destes para pensar o currículo, imerso no caos, no devir, no rizoma, tendo a diferença sempre como eixo central. Corazza (2008, p. 16), em sua radicalidade póscrítica, parte de um princípio curricular: não há currículo, que não considere a realidade, senão como interpretativa ou perspectivista. Tal visão é crucial para entender como a 


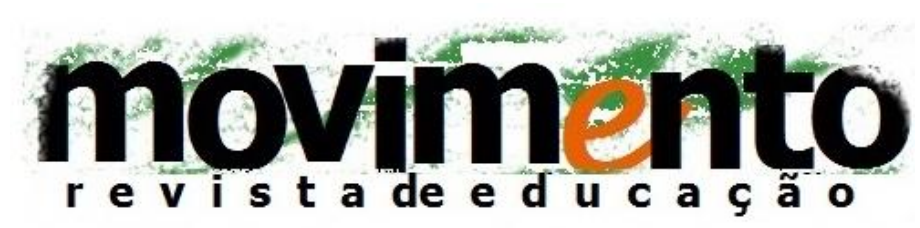

faculdade de educação - programa de pós-graduação em educação

universidade federal fluminense

issn 2359-3296

ano 3 número 5 - 2016

abstração encontra terreno fértil em um contexto teórico que compreende a realidade sempre como um discurso sobre a mesma, ignorando qualquer ideia de realidade factual. Sendo interpretativa e perspectivista, a realidade nunca é em si, pois sempre é na visão de algo/alguém. Dessa forma, oferecer saídas concretas ao professorado é de fato difícil, tendo em vista que tal iniciativa seria interpretada como uma imposição discursiva sobre a realidade pela qual se deseja arbitrariamente modificar. Transformação de sociedade é impossível dentro dessa conjuntura, pois a própria sociedade, como a realidade, não acopla nenhuma ideia estrutural, nem de unidade, nem de totalidade, ficando a cargo de uma questão de olhares e perspectivas sobre as mesmas.

Assim, ao tentar dimensionar sua noção a respeito do que seria um currículo, a autora salienta: Ora, ele é tudo o que se pode dizer e fazer de um currículo, hoje. Um dizerfazer, advindo do acúmulo dos estudos de currículo e das práticas curriculares construídas pela história dos educadores (CORAZZA, 2008, p. 14). A autora prossegue, afirmando que o currículo é o que nos convoca a criar quando abrimos o jornal todo o dia, neste preciso momento, no mundo, na história, e ficamos desassossegados, desconcertados, desalinhados, com a existência dos diferentes e suas diferenças, a quem nos compete educar (idem, p.15). Reitera que o currículo é sempre da ordem do inimaginável e indizível, necessário e ao mesmo tempo impossível, sem dogmas e certezas nos quais, todos os diferentes que trabalhamos, caminhamos, navegamos, possamos então neles viver, com mais singularidade e leveza, liberdade e beleza, alegria e dignidade (idem). Em outro trabalho, a autora sintetiza:

Na perspectiva da teoria pós-crítica, o currículo está em tudo, em todos os espaços, faz questão de ser exercido em qualquer comunidade formal ou informal: local de trabalho, de lazer, campo, cais, ilhas, praças, pátios, associações, ginásios, ruas, assentamentos, parques, viadutos, e até em escolas. Faz questão de ser experienciado em qualquer lugar, onde the seja dada a oportunidade de produzir e contestar verdades, confrontar narrativas e experiências [...] (CORAZZA, 2005, p. 109, grifo nosso). 


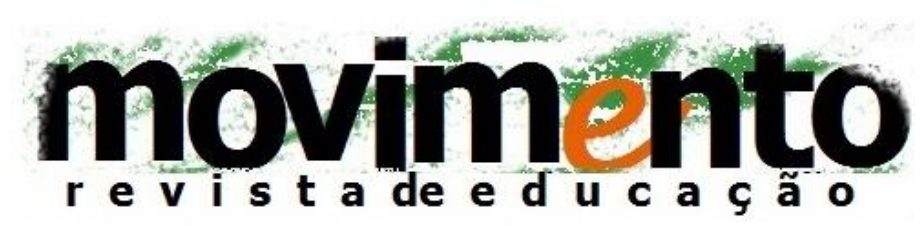

faculdade de educação - programa de pós-graduação em educação

universidade federal fluminense

issn 2359-3296

ano 3 número 5 - 2016

Ao defender que na perspectiva pós-crítica o currículo está em tudo (até nas escolas), pode-se ter a dimensão de como em segundo plano se encontram as demandas imediatas, conflituosas e tensas que envolvem o currículo no cotidiano das escolas. Debater com a devida importância a questão da seleção/exclusão dos conhecimentos, refletir como o currículo pressupõe projetos de sociedade em disputa (GIROUX, 1997; APPLE, 2006) são questões que passam longe de uma concepção pós-crítica radical que ao defender que o currículo está em tudo, flerta com a ideia de que o currículo não está em nada (THIESEN, 2015).

Ao justificar suas pesquisas dentro dessas premissas pós-críticas, Corazza (2008) afirma que suas pesquisas enfatizam um vitalismo curricular, e tece a seguinte explicação a respeito:

A pesquisa enfatiza um vitalismo curricular, desenvolvido em névoas não-eternas, e que acompanha aqueles autores que pensam o nosso presente, ou seja, os contemporâneos de um currículo. Sob a condição que o presente é o que são e, por isso mesmo, o que já deixam de ser, os pesquisadores operam num tempo de coexistência, entre as suas próprias Vidarbos (vidas-obras), as dos currículos e as de seus contemporâneos, superpondo-os numa ordenação estratigráfica; juntamente com outras obras-vidas que atravessam a história da ciência e da filosofia, da literatura e do teatro, da poesia e da pintura, da música e do cinema, da crítica e da clínica (CORAZZA, 2008, p.19).

A sensação, ao ler a descrição, é a de que o radicalismo pós-crítico consiste justamente no grau elevado de abstração oriundo de um pós-estruturalismo elevado às últimas 


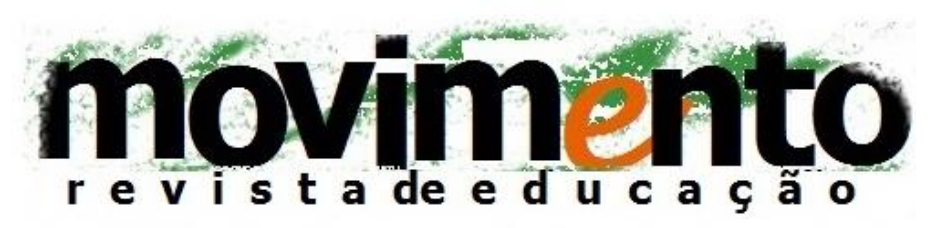

faculdade de educação - programa de pós-graduação em educação

universidade federal fluminense issn 2359-3296

ano 3 número 5 - 2016

consequências. Em outro trabalho, a própria Corazza (2010) consente em uma possível abstração conceitual de suas concepções e em seguida elabora sua justificativa:

Pode ser que um geocurrículo seja tomado como coisa-em-si, abstração conceitual ou verbalista, sem qualquer concretude, impossível de ser relacionado com o observável da experiência. Mas..., em vez da clausura metafísica, consiste em um conjunto de processos auto organizadores, relativos a estratos (orgânicos, físico-químicos, tecno-sociais, bio-políticos); ou seja, numa máquina revolucionária: tanto mais abstrata quanto é real. (CORAZZA, 2010, p.156).

Conforme dito anteriormente, além dos trabalhos dos autores aqui citados, há teses que também mergulham nessas premissas, não por acaso orientadas por alguns destes autores, o que nos faz concluir que evidentemente tais trabalhos não são publicações isoladas de autores eminentes para o campo curricular, ao contrário, teses e dissertações são produzidas sob suas influências indicando que há indícios de uma corrente que aqui nomeamos como pós-estrutural radical.

Tomaremos como exemplo duas teses, filiadas ao Programa de Pós-Graduação em Educação da Universidade Federal do Rio Grande do Sul, orientadas respectivamente por Tomaz Tadeu Silva e Sandra Corazza, para ilustrar o caráter transgressor dos trabalhos, porém, excessivamente abstrato e afastado de discussões concretas relativas ao campo do currículo e a educação de modo mais geral. 


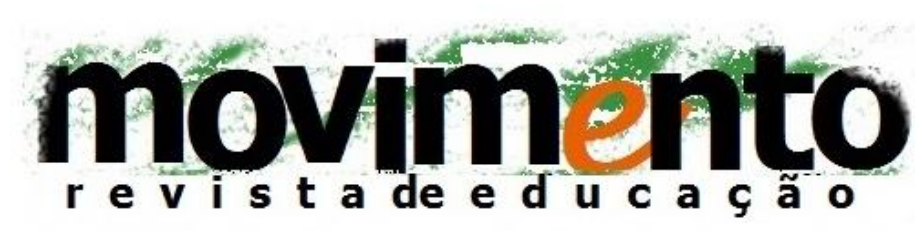

faculdade de educação - programa de pós-graduação em educação

universidade federal fluminense

issn 2359-3296

ano 3 número 5 - 2016

A tese de Jacques (2011), do ponto de vista de sua estruturação, já foge de alguns padrões acadêmicos ao, por exemplo, ser organizada através de pensamentos livres que ora se estruturam em aforismos, ora em poesias, ora em uma espécie de crônica ou ensaio filosófico. Não há capítulos e não há citações, embora no final existam referenciais bibliográficos. Até então, essa questão é de cunho pessoal do autor e orientador do trabalho e nada aqui temos a dizer a respeito dessas questões, primeiro porque não é da alçada desse artigo, e, segundo, porque desestabilizar as formas canônicas de fazer ciência é uma discussão hoje necessária na academia.

A questão então aqui vai pelo conteúdo em si da tese e sua contribuição para oferecer alternativas à educação. Não há uma linha teórica a ser cotejada na tese, e a cada subtítulo somos convidados a leituras poéticas e abstratas que nos parecem nada dizer, embora no fundo, parecem dizer muita coisa. Assim somos instigados a tentar desvendar possíveis figuras de linguagem por detrás de tantos aforismos e versos, correndo o risco de nada conseguir perceber, e até nos sentirmos incapacitados para tal desafio. São exemplos de tais construções:

Páginas agonizantes.

Sofre até a última linha. Desliza pelo risco até a margem. Cai novamente, novo risco. Até o final sofre escorregando. Se não houver pausa, não pára. Infinitamente ocupando letras, preenchendo as cartas. Notícias de além mar. Haverá um tempo em que tudo se transformará em páginas escritas. Um tempo em que os escritores terão transformado a superfície da água em pedra para escrever. (JACQUES, 2011, p.37)

\section{Sabores.}

Da língua gustativa. Experimenta cada canto numa vontade azeda, amarga, salgada e doce. Cada qual esperando ressaltar umas sobre as outras. Cada qual querendo apagar uma a outra. Como numa batalha onde esta somente um. Lado. Mas do sabor importa o todo. O quanto como. (JACQUES, 2011, p. 66) 


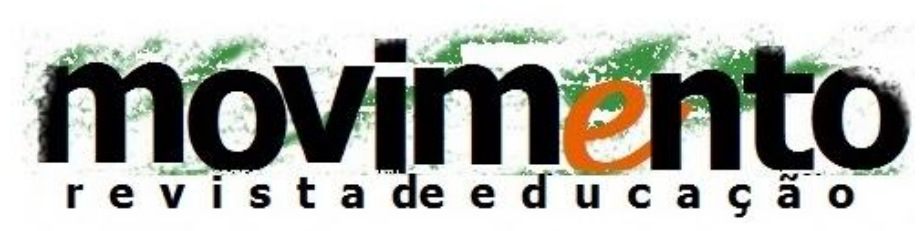

faculdade de educação - programa de pós-graduação em educação

universidade federal fluminense

issn 2359-3296

ano 3 número 5 - 2016

Não é intenção aqui, evidente, interpretar tais linhas, e sim, demonstrar transgressões e influências pós-estruturais extremas em trabalhos acadêmicos que acabam por flertar muito mais com a filosofia do que propriamente com o campo curricular especificamente, ou com a educação no âmbito geral. Enxergamos pós-estruturalismo em tal tese, no conjunto de referenciais bibliográficos, que embora não citados ao longo do texto, ao final, as várias referências a autores como Deleuze, Derrida e Guatari indicam claramente tais influências.

Tal estrutura poética, metafórica e abstrata, permanece em outra tese, orientada também por Tomaz Tadeu. O trabalho de Araújo (2007) tem estruturação bem semelhante ao de Jacques (2011) no tocante à transgressão teórica, científica e normativa. Existem outras teses orientadas pelo mesmo autor, que seguem essa mesma não-estrutura (GIROTTO, 2011). Curioso, pois a transgressão, nesse contexto, parece ser a norma e o padrão a ser seguido. Nesse caso, o padrão é despadronizar. E ao fazê-lo, padroniza-se a transgressão. Na tese de Araújo (2007) podemos encontrar construções semelhantes à tese anterior:

Uma bola. Uma cabeça. Uma criança. Gigante com cabeça-mula. Cresce por entre a bola e uma criança. Pica. Criança pica. Bola pica. Pica bola. Bicicleta cai. Criança também. Um aro gira. Som do tempo. No meio um par de olhos observa. Formula. Ao lado. Tinta. Papel. Gritos. Correria e desvario. Cabeça gira. Murcha a bola. (ARAÚJO, 2007, p.69)

[...] Cobertas caem. Mãos não param. Contatar. Atritar. Respirar. Descompasso. Desejar. Pulsa corpo. Pulsão. Lábios. Envolver nuca. Dedos. Alastrar. Contornar seios. Mamilos eretos. Toque. Um dedo. Contornar Primeiros suspiros. Língua. Encontrar mamilos. Mãos. Contornar coxas. Ouriçar pelos. (ARAÚJO, 2007, p.77) 


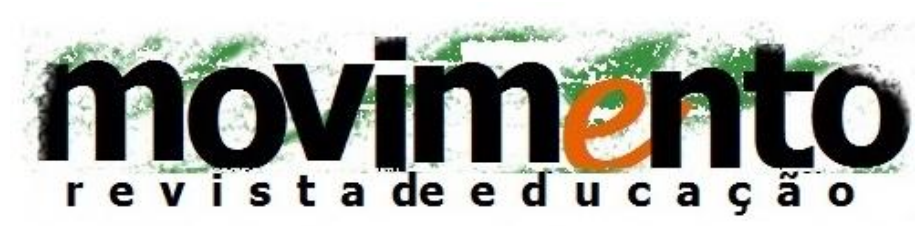

faculdade de educação - programa de pós-graduação em educação

universidade federal fluminense issn 2359-3296

ano 3 número 5 - 2016

Quando Moreira (2010) afirma que o campo curricular tem passado por uma filosofização, o eminente autor quis dizer justamente que as influências pósmodernas e pós-estruturais ao campo, em algumas vertentes específicas, têm caminhado para a produção de discursos dispersos, vagos, abstratos, que não oferecem saídas concretas aos atores educacionais inseridos na dura batalha do dia a dia. Em alguns de seus trabalhos, Antônio Flávio B. Moreira já chamava atenção para o que estamos enfatizando aqui:

Ao que parece, o campo do currículo caminhou, nos anos noventa, para uma situação de crise: dispersão, sofisticação teórica, mas ainda reduzida visibilidade nas escolas. É esse o quadro que o estado da arte nos anos noventa dominantemente sugere. (MOREIRA, 2001, p.38)

[...] Houve muitos ganhos, mas a vara curvou-se demais para o lado da cultura, dela fazendo um grande guarda-chuva, capaz de tudo abrigar. Cultura acabou sendo tudo e, ao acabar sendo tudo, terminou com dificuldade de ser alguma coisa mais concreta. Com o foco na cultura, surgiram estudos extremamente criativos, inventivos, originais e que contribuíram muito para o campo, mas surgiram também estudos pouco expressivos e pouco relevantes para a compreensão do fenômeno (MOREIRA, 2010, p.46).

Thiesen (2015) tece críticas em relação às formulações de corte pós-crítico excessivamente pós-estruturalista no tocante a seu afastamento das discussões em torno das políticas curriculares. O autor faz provocações que são importantes:

[...] quais sentidos explicariam os descompassos entre o que se produz de conhecimento no campo e o que se propõe como política? Afinal, o que circulam nestas fendas ou interfaces? Na radicalidade, ainda se poderia perguntar: a que serve a pesquisa em currículo? (THIESEN, 2015, p.12). 


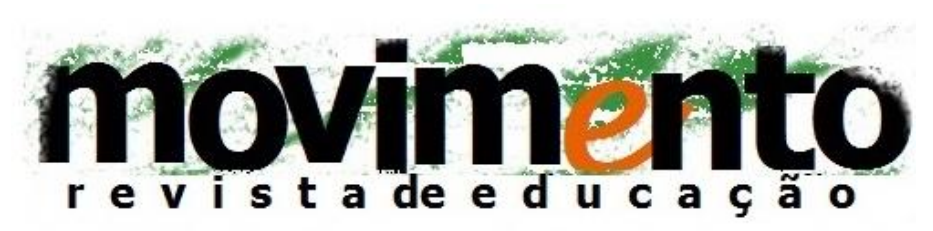

faculdade de educação - programa de pós-graduação em educação

universidade federal fluminense

issn 2359-3296

ano 3 número 5 - 2016

Perguntar a que serve as pesquisas em currículo e educação é fundamental e nos remete a outras questões centrais ao campo curricular: $O$ que os alunos devem aprender e o que se deve ensinar nas escolas? Que conhecimentos são considerados legítimos e quem os legitima historicamente? Que conhecimentos são silenciados e marginalizados? Como garantir o acesso aos conhecimentos construídos historicamente sem descontextualizá-los das experiências e saberes advindos das realidades locais? Ao atuar sempre no âmbito da seleção de conhecimentos, o currículo seleciona quais culturas? Que projetos de sociedade desejamos tentar construir e para que servem, afinal, as escolas? Nesse sentido, estamos de acordo com os trabalhos recentes de Michael Young e Antônio Flávio Barbosa Moreira que chamam atenção para a necessidade de o campo do currículo não se esquecer de suas bases de sustentação.

Ainda que a proposta de Young $(2007,2011,2013)$ associada à defesa de um conhecimento poderoso não seja a desse artigo, sua preocupação em relação ao campo é por nós acolhida: De quais questões deve tratar uma teoria do currículo? (YOUNG, 2013, p.226)

Dessa forma, advoga-se aqui a idéia de que tais recortes radicais pósestruturais, ao se apropriarem de filósofos pós-estruturalistas que não versavam sobre Educação, muito menos sobre currículo, (Deleuze, Derrida, Guatarri) provocaram, de um lado, a ampliação do currículo sob outras bases conceituais, enriquecendo ainda mais o já polissêmico campo. Mas de outro lado, contribuiuse para uma excessiva abstração filosófica que se arvora de termos metafóricos, poéticos, e que acaba por se distanciar dos objetos centrais do campo curricular, e pouco contribui para formulação de alternativas concretas aos sujeitos escolares. Essas apropriações são denominadas aqui de estudos pós-críticos radicais. 


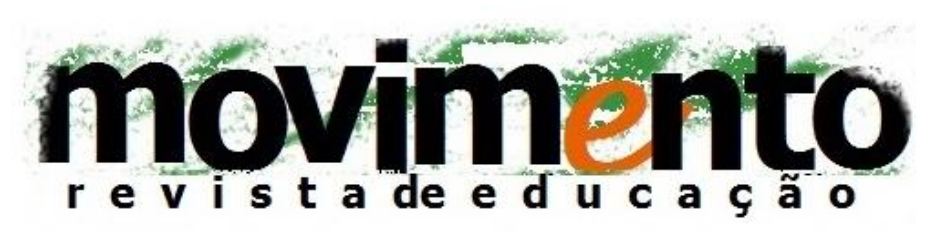

faculdade de educação - programa de pós-graduação em educação

universidade federal fluminense issn 2359-3296

ano 3 número 5 - 2016

Além do mais, tais acepções acabam por induzir a uma compreensão de que os estudos de linhagem crítica estariam superados pelas vertentes ditas póscríticas. Como salientamos, cria-se uma visão pejorativa da teoria curricular crítica, como aquela estagnada que continua a defender premissas típicas do sujeito centrado-moderno e que possui forte viés determinista.

O que já esboçamos e que agora pretendemos aprofundar é que perceber assim a teoria curricular crítica é desconsiderar sua ressignificação teórica, e desconhecer as mudanças pelos quais seus teóricos passaram, no sentido inclusive de acolher ideários pós-modernos, sem, contudo, cair nas armadilhas da total abstração travestida de transgressão/desconstrução/caos rizomático. Defenderemos aqui, portanto, uma concepção de teoria crítica em diálogo com vertentes pós, recusando qualquer ideia de que ela estaria superada, e sim, ressaltando suas contribuições ao campo curricular, a partir de suas ressignificações teóricas.

Notas conclusivas: por uma concepção curricular crítica em diálogo

Como já mencionado, Silva (2009) decreta que o advento do pós-modernismo resulta no fim da chamada pedagogia crítica, noção esta que se pretende aqui problematizar, na busca de uma noção que esteja para além da dicotomia crítico e pós-crítico. Acolher as contribuições do pós-modernismo e pós-estruturalismo, sem perder de vista alguns ideais da teoria crítica, são saídas viáveis que visam aproximar críticos e pós-críticos, buscando uma espécie de síntese a respeito do que cada vertente pode oferecer. Giroux (1993,1997), McLaren (1997) e Freire 


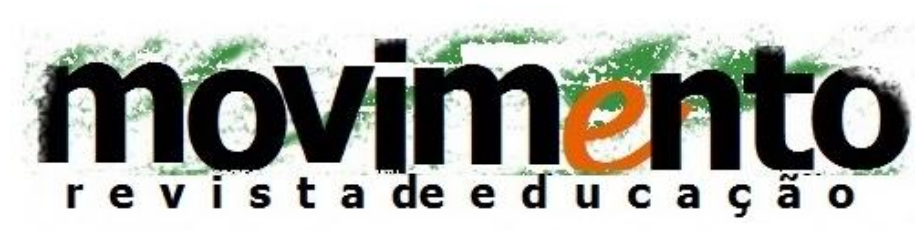

faculdade de educação - programa de pós-graduação em educação

universidade federal fluminense

issn 2359-3296

ano 3 número 5 - 2016

$(1992,1993)$ produzem essa síntese entre ambas vertentes, dificultando a exata noção de onde se termina uma teoria crítica e onde se inicia uma concepção pós-crítica. Para esses autores há um híbrido de contribuições e é difícil situálos em apenas uma das correntes.

Conforme Moreira (2010) já salientara, a teoria crítica curricular a partir da década de noventa se hibridizou em certa medida, acolhendo algumas contribuições pós-modernas no que diz respeito à ressignificação de categorias conceituais como cultura, linguagem, etnia e gênero.

As críticas feitas por Tomaz Tadeu Silva à teoria crítica ilustram como que o risco de se cair em um reducionismo teórico é real, se fixarmos os sentidos dados à teoria crítica, ancorados em um quadro teórico estático. Giroux $(1993,1997)$ defende um diálogo entre críticos e pós-modernos, e, na mesma direção, caminham McLaren (1997) e Moreira (2003). Os dois primeiros são muito influenciados por Paulo Freire. É como se estes autores deslizassem (MACEDO, 2012) entre teorias críticas e pós-críticas, absorvendo suas contribuições, dificultando de modo considerável a demarcação dessas fronteiras, por se tratarem de híbridos teóricos, termo empreendido por Lopes (2013).

A década de 1960-1970, em que sociólogos críticos pensavam a sociedade enfatizando a reprodução, cumpriu importante papel ao denunciar a relação íntima entre capitalismo, ideologia e instituição escolar. No entanto, marcados pelo contexto, no qual estavam inseridos, vários sociólogos críticos adotaram um tom fatalista no tocante à sociedade como um todo. Tais fatalismos impossibilitadores foram ressignificados por teóricos críticos do currículo, que, influenciados pelas ditas teorias da reprodução (SAVIANI, 2007), passaram a reconsiderá-la e reinterpretá-la sob diferentes prismas. De modo que, 


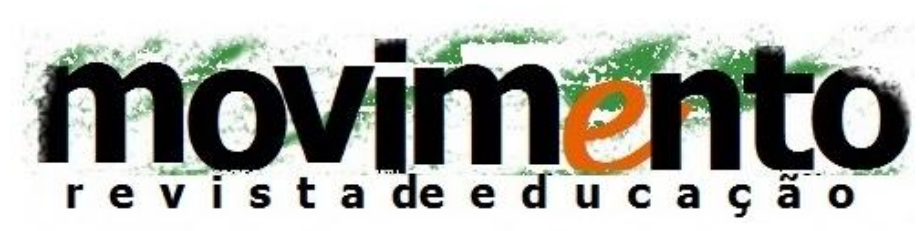

faculdade de educação - programa de pós-graduação em educação

universidade federal fluminense

issn 2359-3296

ano 3 número 5 - 2016

atualmente, a teoria crítica está longe de se limitar ao reprodutivismo, ao fatalismo, ao paradigma moderno de sujeito, plenamente racional e autônomo. Paulo Freire talvez seja a síntese, justamente, do hibridismo teórico que coloca uma névoa entre as fronteiras críticas e pós-críticas.

Embora Freire (1992, 1993, 2013) não abandone suas utopias (inéditos viáveis), sua visão do todo e nem o caráter propositivo de sua obra, ele ainda assim não concebe o sujeito como plenamente racional, autônomo, nem ignora o devir, tão referendado por teóricos do currículo de influência deleuziana. Ao contrário, vê o sujeito como inacabado, inconcluso, tal qual a sociedade, num processo em que nunca se é, e sim, está sendo. Freire (1993) desconfia ainda dos determinismos, mecanicismos e linearidade dos processos históricos. Assim, chega a se intitular pós-moderno progressista:

Para superarmos, de um lado, os sectarismos fundados nas verdades universais e únicas; do outro, as acomodações pragmáticas aos fatos, como se eles tivessem virado imutáveis, tão ao gosto de posições modernas, os primeiros, e modernistas, as segundas, termos de ser pós-modernamente radicais e utópicos. Progressistas. (FREIRE, 1992, p. 33)

O que a pós-modernidade progressista nos coloca, é a compreensão realmente dialética da confrontação e dos conflitos e não sua inteligência mecanicista [...] Em lugar da decretação de uma nova história sem classes sociais, sem ideologia, sem luta, sem utopia e sem sonho, o que a cotidianeidade mundial nega contundentemente, o que temos que fazer é repor o ser humano que atua, que odeia, que cria e recria, que sabe e que ignora, que se afirma e que se nega, que constrói e destrói, que é tanto o que herda quanto o que adquire, no centro, das nossas preocupações (FREIRE, 1993, p.15).

Tal pós-modernidade progressista, para Freire $(1992,1993)$, é justamente o acolhimento de contribuições dessas vertentes pós, mas que não descambem para a eliminação radical da ideia de sujeito, como defende Silva (2000), anulando a intervenção do sujeito em sua realidade, desmontando a utopia. 


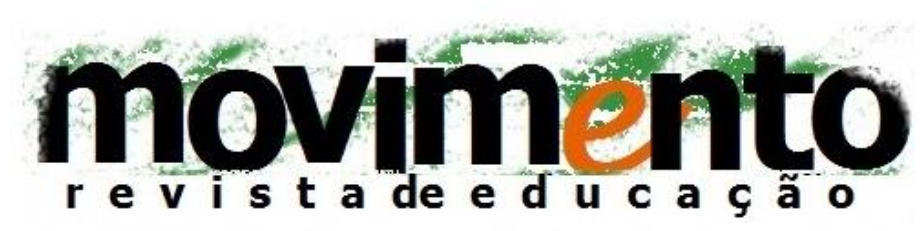

faculdade de educação - programa de pós-graduação em educação

universidade federal fluminense

issn 2359-3296

ano 3 número 5 - 2016

Tornar a pós-modernidade, nas palavras freirianas, progressista, não seria justamente hibridizá-la com uma concepção crítica? No campo curricular, é justamente isso que fazem Giroux $(1993,1997)$ e McLaren (1997). Antônio Flávio Barbosa Moreira é percebido da mesma maneira por Macedo (2012, p.726):

[...] a dificuldade de situar o pensamento de Moreira entre as tradições crítica e pós-estruturais não ocorre apenas em relação à temática do conhecimento, mas é nela que adquire um tom mais dramático. Em diferentes trabalhos, o autor argumenta em favor das utopias modernas para a escola, definindo-se como um teórico crítico. Sua descrição da contemporaneidade, no entanto, se dá no quadro das preocupações manifestadas pelo pensamento pós-crítico. Questões em torno da cultura, da fragmentação identitária, do relativismo do conhecimento surgem mescladas com a aposta nessas utopias. Há um deslizamento entre uma descrição que leva em conta os desafios da teoria pós-crítica e a crença em um projeto moderno de superação da crise da sociedade atual.

Deslizar entre teoria crítica e pós-crítica, do ponto de vista de Scocuglia (1999, p.175), é transitar pela representação e apresentação da própria realidade, é não abdicar da totalidade, mas não ignorar a diferença, [...] o surpreendente, o instintivo, o sentimento, as escolhas individuais, os fragmentos. Porém, isso não implica, no que o autor denomina como ingenuidade em negar as grandes estruturas (SCOCUGLIA, 1999, p.177).

A influência que Paulo Freire exerce em Giroux (1993,1997), McLaren (1997) e Apple (2006) é um sinal claro de como tais teóricos críticos específicos do currículo não se limitaram ao fatalismo, ao economicismo, ao determinismo e ao reprodutivismo, ao contrário, refinaram suas teorias, acolhendo pontos importantes dos teóricos reprodutivistas, mas defendendo a pedagogia como possibilidade de resistência no centro dos processos históricos, sem deixar de reconhecer a importância de articular o conhecimento e a cultura como temáticas 


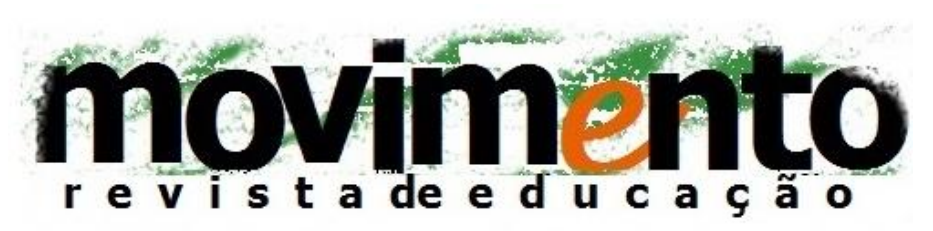

faculdade de educação - programa de pós-graduação em educação

universidade federal fluminense issn 2359-3296

ano 3 número 5 - 2016

centrais ao currículo. Absorvem também, sem perder suas utopias e projetos de sociedade, as contribuições pós-modernas e pós-estruturais, ao problematizar e questionar os universalismos. Percebem a linguagem e o discurso como fontes de poder, compreendendo o sujeito como inconcluso e não plenamente racional. Desconfiam do eurocentrismo, conclamando outras visões de mundo, sobretudo a dos marginalizados históricos que buscam voz e vez nos currículos.

Moreira (2010) analisa que a teoria crítica possui certas fases de desenvolvimento, de modo que não pode ser entendida de modo homogêneo e estático. A quarta fase do desenvolvimento da vertente crítica se inicia nos anos de 1990, a partir de questionamentos a respeito do neomarxismo predominante na década (fase) anterior. Tais críticas são oriundas justamente de vertentes pós-modernas e pós-estruturais, o que obriga a teoria crítica a revisitar-se, ponderar seus rumos e, inevitavelmente, absorver contribuições.

Giroux (1993) já alertara sobre a possibilidade desse diálogo, ressaltando que a teoria crítica poderia aproveitar de algumas percepções do pós-modernismo e pós-estruturalismo, porém, sem perder de vista o compromisso com a justiça social, com a democracia, com a libertação e crítica às desigualdades.

Giroux (1993) e McLaren (1997) defendem que não se deve perder de vista a noção de totalidade, embora também não se deva desconsiderar a inserção da diferença dentro desse aspecto mais total. Precisamos de teorias que expressem e articulem a diferença, mas precisamos também compreender como as relações nas quais as diferenças são constituídas operam como parte de um conjunto mais amplo de práticas sociais, políticas e culturais (GIROUX, 1993, p.53). 


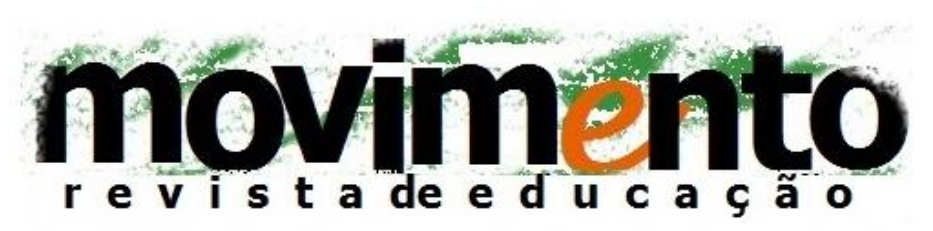

faculdade de educação - programa de pós-graduação em educação

universidade federal fluminense issn 2359-3296

ano 3 número 5 - 2016

Questionar, problematizar e desconfiar dos paradigmas da modernidade para Giroux (1993) é crucial para os teóricos críticos, sobretudo, na concepção de conhecimento que emana do ideário moderno. Um conhecimento permeado por valores essencialmente europeus, cristão, branco e masculino, que não raramente cria dicotomias entre o que é considerado legítimo, associado à cultura de elite, daquilo que é ilegítimo, oriundo da cultura popular. Contestar o modernismo significa redesenhar e remapear a própria natureza de nossa geografia social, política e cultural (GIROUX, 1993, p.42). É nesse sentido que Giroux (1993, p.42) argumenta que algumas contestações feitas pelo pósmodernismo e pós-estruturalismo são importantes porque promete desterritorializar e redesenhar as fronteiras políticas, sociais e culturais do modernismo, insistindo ao mesmo tempo numa política da diferença racial, étnica e de gênero.

O autor faz uma ressalva importante: a crítica pós-moderna oferece saídas progressistas, mas também reacionárias e, por isso mesmo, precisam ser examinadas com cautela se caso se deseja acolher criticamente algumas de suas contribuições. A grande contribuição de Giroux (1993) se dá no argumento de que a base de uma pedagogia crítica não necessita ser constituída a partir de uma escolha entre modernismo e pós-modernismo, ou estruturalismo e pósestruturalismo. Giroux (1993), amparado em Ernesto Laclau, defende que o pósmodernismo é um modo diferente de modular temas e categorias da modernidade, não necessariamente significa uma brusca ruptura. Em outras palavras, o que Giroux (1993) pretende é uma combinação entre aportes pósmodernos e concepções de uma teoria crítica (radical, nos termos do autor).

A combinação entre o discurso pós-moderno e o crítico necessita que a noção da totalidade seja adotada mais como um dispositivo heurístico do que como 


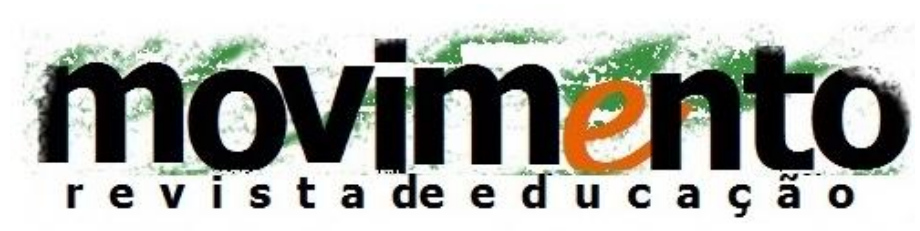

faculdade de educação - programa de pós-graduação em educação

universidade federal fluminense issn 2359-3296

ano 3 número 5 - 2016

uma categoria ontológica (GIROUX, 1993, p.53). Necessitamos de teorias que articulem a diferença, o particular, porém precisamos compreender como operam as relações nas quais as diferenças se constituem, como parte de um conjunto mais amplo de práticas sociais, políticas e culturais.

Compreende-se que é equivocado acusar as teorias críticas de defenderem modelos de sociedade, de escolas, de como ensinar, como o fez Silva (2000). Confunde-se, por vezes, ser propositivo (premissa básica da teoria crítica) com um rompante em querer ditar a verdade, impor um discurso. No entanto, são coisas distintas. Apple (2006), McLaren (1997), Giroux (1997), Freire (1992, 1993, 2013) explanaram em suas obras a respeito da total impossibilidade, por parte de vertentes críticas, de querer ditar um modelo crítico homogêneo às realidades ou de querer instituir um modo de ser professor, um modo de ensinar, tipicamente críticos.

A teoria crítica curricular amparada nesses autores é uma concepção do diálogo nos moldes freireanos: nunca para o sujeito e sim com ele. A teoria crítica se não ressalta enfaticamente a diferença como a pós-crítica, não a anula ao abarcar a totalidade, nem compreende a classe social como o único componente de explicação das relações sociais. Apple e Au (2011), mesmo ao tomarem o neomarxismo como base de análise, chamaram atenção para a insuficiência, nos dias atuais, do conceito de classe para explicar toda a dinâmica social e também para a importância de não desdobrar as análises sobre as relações sociais em um economicismo ortodoxo. Freire (1992) chama a atenção para a luta de classes como um dos motores, e não o motor principal da história.

É necessário compreender a teoria crítica, amparada sob uma perspectiva de pedagogia crítica (MCLAREN, 1997), dentro dos seguintes princípios: de uma 


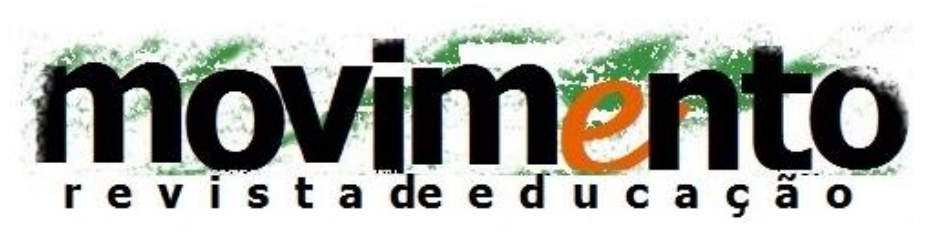

faculdade de educação - programa de pós-graduação em educação

universidade federal fluminense issn 2359-3296

ano 3 número 5 - 2016

teoria que vem se desenvolvendo continuamente, recusando qualquer ortodoxia, desconfiando dos fatalismos e das verdades universais, dialogando e se abrindo para a pluralidade de vertentes, incluindo aí as de raízes pós-modernas. Anular as contribuições da vertente curricular crítica pode ocasionar em um risco de tornar as influências pós-modernas e pós-estruturais, tão radicais no campo curricular, a ponto de cair em certa abstração total que dificulta até mesmo a oportunidade de oferecer saídas ao professorado sobre o que fazer na segundafeira de manhã (MOREIRA, 2001, p. 40).

Onde então reside a fronteira entre críticos e pós-críticos? Problematizar tais correntes críticas e pós-críticas é se permitir misturá-las, e enxergar suas ênfases distintas, mais do que suas potenciais rupturas. Trata-se de colocá-las em disputa, como é o campo curricular, mas não no sentido de uma que mata a outra, mas sim no sentido de atuar na fronteira entre ambas, na tênue demarcação (provisória e contingencial) que as difere.

$\mathrm{Na}$ mistura de possibilidades, na neblina que se forma sobre o quadro que diferencia tais vertentes, a utopia pode caminhar para pós-crítico enquanto a cultura pode ser central também aos teóricos críticos. Há híbridos teóricos e deslizamentos que estão para além do enquadramento. Reitera-se aqui a necessidade de se repensar as categorias crítica e pós-crítica seguindo o rastro sugerido por Henri Giroux: a de que a teoria pós-crítica é também uma teoria crítica com enfoques diferenciados. Dessa forma, o prefixo pós, que permite a inferência de superação de uma vertente sobre outra, pode contribuir para criar dicotomias entre as terminologias que acabam por desconsiderar as contínuas ressignificações teóricas que possibilitam diversos pontos de encontro entre as vertentes. 


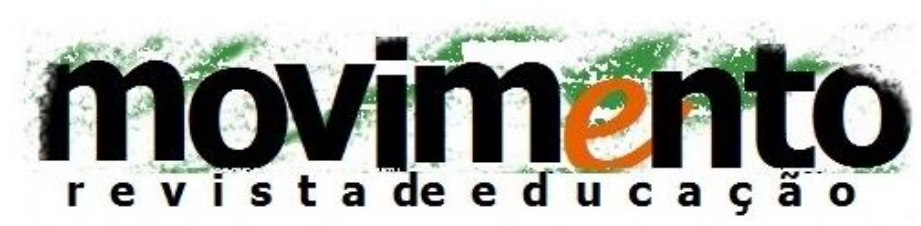

faculdade de educação - programa de pós-graduação em educação

universidade federal fluminense issn 2359-3296

ano 3 número 5 - 2016

\section{REFERÊNCIAS}

APPLE, Michael. Ideologia e Currículo. 3ed. Porto Alegre: Artmed, 2006.

APPLE, Michael. AU, Wayne. Repensando a reprodução: o neomarxismo na teoria da educação crítica. In: APPLE, Michael. AU, Wayne, GANDIN, Luís Armando. Educação crítica. Análise Internacional. Porto Alegre: Artmed, p. $100-114,2011$.

ARAÚJO, Róger Albernaz. $1 / 2$ dia $1 / 2$ noite. Tese (doutorado). Universidade Federal do Rio Grande do Sul. Faculdade de Educação. Programa de Pós-Graduação em Educação, 2007, Porto Alegre, 161p.

CORAZZA, Sandra. O Que quer um currículo? Petrópolis: Vozes, 2001.

CORAZZA, Sandra. Diferença pura de um pós-currículo. In LOPES, Alice; MACEDO, Elizabeth. (Orgs.). Currículo: debates contemporâneos. São Paulo: Cortez, 2005, p. 103-114.

CORAZZA, Sandra. Os sentidos do currículo. Revista Teias, v. 11, n. 22, p. 149164, maio/agosto 2010.

CORAZZA, Sandra Mara. Currículo na contemporaneidade. Conferência. Formação Continuada: UNIFEBE (Brusque) e FURB (Blumenau) Brusque, Blumenau, SC, 21, 22 de julho de 2008. Disponível:

http://www.unifebe.edu.br/04_proeng/formacao_continuada/2008_2/material_palestras/ curriculo_na_contemporaneidade.pdf. Acesso: jul/2016.

DIAS, Rosanne Evangelista. LOEPS, Alice Casimiro. Sentidos da prática nas políticas de currículo para a formação de professores. Currículo sem Fronteiras. V..9, n.2, p.7999, Jul/Dez 2009.

EAGLETON, Terry. Depois da teoria - um olhar sobre os estudos culturais e o pós-modernismo. Rio de Janeiro: Civilização Brasileira, 2005 


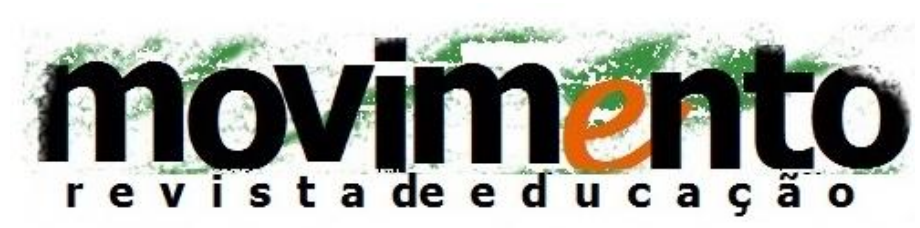

faculdade de educação - programa de pós-graduação em educação

universidade federal fluminense

issn 2359-3296

ano 3 número 5 - 2016

FERRAÇO, Carlos Eduardo. CARVALHO, Janete Magalhães. Currículo, cotidiano e conversações. Revista e-curriculum. São Paulo, v.8 n.2, p.1-17, ago/2012. Disponível em: http://revistas.pucsp.br/index.php/curriculum/article/view/10985. Acessado em: julho/2016.

FREIRE, Paulo. Pedagogia da Esperança. 11. ed. São Paulo: Paz e Terra, 1992.

FREIRE, Paulo. Política e educação. São Paulo: Cortez, 1993.

FREIRE, Paulo. Pedagogia do oprimido. 33.ed. Rio de Janeiro: Paz e Terra, 2013.

GALLO, Sílvio. Educação: entre a subjetivação e a singularidade. Educação (UFSM), v. 35, p. 229-243, 2010.

GIROTTO, Nara Lúcia. Carmesim. Tese (doutorado). Universidade Federal do Rio Grande do Sul. Faculdade de Educação. Programa de Pós-Graduação em Educação, 2011, Porto Alegre, 169p.

GIROUX, Henry. O Pós-Modernismo e o discurso da crítica educacional. In: SILVA, Tomaz Tadeu. (Org.). Teoria educacional crítica em tempos modernos. Porto Alegre: Artes Médicas, p.41-73, 1993.

GIROUX, Henri. Os professores como intelectuais: rumo a uma pedagogia crítica da aprendizagem. Porto Alegre: Artes Médicas, 1997.

LOPES, Alice Casimiro. MACEDO, Elizabeth. Contribuições de Stephen Ball para o estudo de Políticas de Currículo. Ball, Stephen; Mainardes, Jefferson (org). In: Políticas Educacionais: questões e dilemas. São Paulo: Cortez, 2011.

LOPES, Alice Ribeiro Casimiro. Teorias pós-críticas, política e currículo. Educação, Sociedade \& Culturas, № 39, 2013.

LYOTARD, Jean-François. A condição pós-Moderna. Trad. Ricardo Corrêa Barbosa. Rio de Janeiro: José Olympio, 1984. 


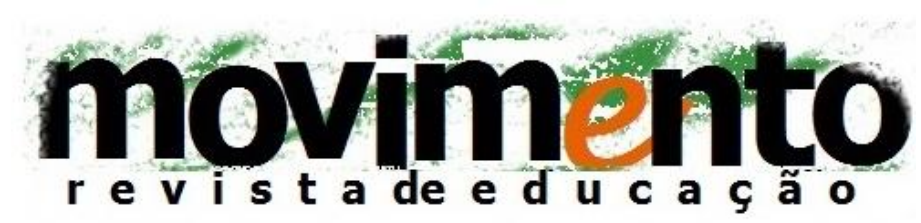

faculdade de educação - programa de pós-graduação em educação

universidade federal fluminense

issn 2359-3296

ano 3 número 5 - 2016

JACQUES, Carmen. Palavra crítica. Tese (doutorado). Universidade Federal do Rio Grande do Sul. Faculdade de Educação. Programa de Pós-Graduação em Educação, 2011, Porto Alegre, 183p.

MACEDO, Elizabeth. Currículo como espaço-tempo de fronteira cultural. Revista Brasileira de Educação, v. 11, n. 32 , p. 285-296, 2006.

MACEDO, Elizabeth. Currículo e conhecimento: aproximações entre educação e ensino. Cadernos de Pesquisa, v.42 n.147 p.716-737, 2012.

MCLAREN, Peter. Pós-Modernismo, Pós-Colonialismo e Pedagogia. In: SILVA, Tomaz Tadeu. (Org.). Teoria educacional crítica em tempos modernos. Porto Alegre: Artes Médicas, p.9-41, 1993.

MCLAREN, Peter. A vida nas escolas. Uma introdução á pedagogia crítica nos fundamentos da educação. 2ed. Porto Alegre: Artes Médicas, 1997.

MOREIRA, Antônio Flávio Barbosa. O Campo do Currículo no Brasil: os anos noventa. Currículo sem Fronteiras, v.1, n.1, p.35-49, 2001.

MOREIRA, Antônio Flávio Barbosa (Org.). Currículo: questões atuais. 7ed. Campinas, SP: Papirus, 2003.

MOREIRA, Antônio Flávio Barbosa. A configuração atual dos estudos curriculares: a crise da teoria crítica. In: PARAíSO, Marlucy. (Org.). Antonio Flavio Barbosa Moreira: pesquisador em currículo. Belo Horizonte: Autentica, p. 95-115, 2010.

OLIVEIRA, Inês Barbosa. Currículo e processos de aprendizagem ensino: Políticaspráticas Educacionais Cotidianas. Currículo sem Fronteiras, v. 13, n. 3, p. 375-391, set./dez. 2013.

PACHECO, José Augusto. Para a noção de transformação curricular. Cadernos de Pesquisa, v.46, n.159, p.64-77, 2016. 


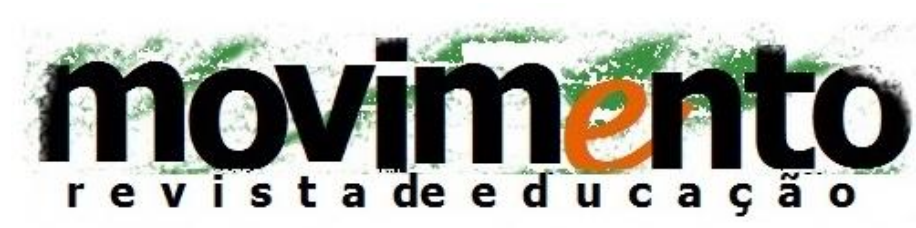

faculdade de educação - programa de pós-graduação em educação

universidade federal fluminense

issn 2359-3296

ano 3 número 5 - 2016

PARAÍSO, Marlucy. Um currículo entre formas e forças. Educação (Porto Alegre, impresso), v. 38, n. 1, p. 49-58, jan.-abr. 2015.

PEREIRA, Talita Vidal. Currículo como teia de significados. Revista Teias, v.12, n.27, p.161- 176, 2012.

PETERS, Michael. Pós-estruturalismo e filosofia da diferença. Tradução: Tomaz Tadeu da Silva. Belo Horizonte: Autêntica, 2000.

SAVIANI, Dermeval. Epistemologia e teorias da educação no Brasil. Proposições, v. 18, n. 1(52), p. 15-27, 2007.

SCOCUGLIA, Afonso Celso. A História das Ideias de Paulo Freire e a atual crise de paradigmas. 2. ed. João Pessoa: Ed. Universitária / UFPB, 1999.

SCOCUGLIA, Afonso Celso. Paulo Freire e a conscientização na transição pósmoderna. Educação, Sociedade \& Culturas, nํ23, p.21-42, 2005.

SILVA, Tomaz Tadeu. Monstros, ciborgues e clones: os fantasmas da Pedagogia Crítica. In: SILVA, Tomaz Tadeu. Pedagogia dos monstros: Os prazeres e os perigos da confusão de fronteiras. Belo Horizonte: Autêntica, 2000.

SILVA, Tomaz Tadeu. Documentos de identidade: uma introdução às teorias do currículo. 3 ed. - Belo Horizonte: Autêntica, 2009.

SILVA, Tomaz Tadeu. 0 currículo como fetiche: a poética e a política do texto curricular. Belo Horizonte: Autêntica, 2010.

THIESEN, Juares da Silva. Virada epistemológica do campo curricular: reflexos nas políticas de currículo e em proposições de interesse privado; anais da 30a Reunião Anual da ANPEd. Florianópolis, ANPEd, 2015.

TOURAINE, Alan. Crítica da Modernidade. Petrópolis: Vozes. 2008.

YOUNG, Michael. Para que servem as escolas? Educ. Soc., Campinas, vol. 28, n. 101, p. 1287-1302, 2007.

YOUNG, Michael. O futuro da educação em uma sociedade do conhecimento: o argumento radical em defesa de um currículo centrado em disciplinas. Revista Brasileira de Educação, v. 16 n. 48, 2011. 


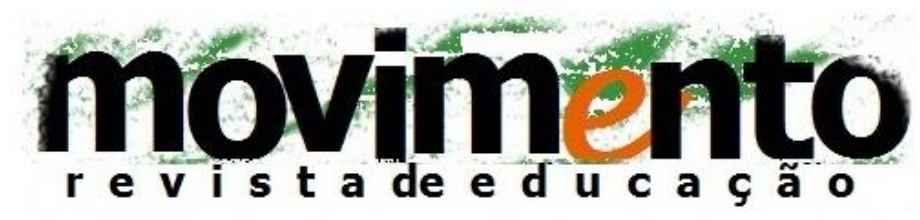

faculdade de educação - programa de pós-graduação em educação

universidade federal fluminense issn 2359-3296

ano 3 número 5 - 2016

YOUNG, Michael. Superando a crise na teoria do currículo: uma abordagem baseada no conhecimento. Cadernos CENPEC, São Paulo, v.3, n.2, p.225-250, 2013. 